\title{
The Sarbanes-Oxley Act and Corporate Investment: A Structural Assessment*
}

\author{
Qiang Kang ${ }^{\dagger}$ \\ University of Miami
}

\author{
Qiao Liu $\ddagger$ \\ University of Hong Kong
}

This Draft: July 2009

\author{
Rong $\mathrm{Qi}^{\S}$ \\ St. John's University
}

\begin{abstract}
We assess the impact of the Sarbanes-Oxley Act of 2002 on corporate investment in an investment Euler equation framework, where a dummy for the passage of the Act is allowed to affect the rate at which managers discount future investment payoffs. Using generalized method of moments estimators, we find that the rate U.S. firm managers apply to discount investment projects rises significantly after 2002, while the discount rate for U.K. firms remains unchanged. The effects of the legislation on corporate investment are asymmetric, and are much more significant among relatively small firms. We also find that well-governed firms, firms with a credit rating, and accelerated filers of Section 404 of the Act have become more cautious about investment.
\end{abstract}

JEL Classification: G18, G31, G34, K22, E22

Keywords: Sarbanes-Oxley Act, investment Euler equation, investment-implied discount rate, corporate governance

\footnotetext{
${ }^{*}$ We are grateful to an anonymous referee for numerous constructive comments that have significantly reshaped and improved the paper. We thank Vidhi Chhaochharia, Xi Li, James Vere, Steve Xu, and Lu Zhang for comments on earlier drafts of the paper, and Yong Wei for able research assistance. We also thank Toni Whited for kindly sharing programming code and offering computation suggestions. Financial support from the Research Grants Commission of the Hong Kong Special Administrative Region, China (Projects HKU7472/06H and HKU747107H) is gratefully acknowledged. All remaining errors are ours.

${ }^{\dagger}$ Finance Department, University of Miami, P.O. Box 248094, Coral Gables, FL 33124-6552. Phone: (305)2848286. Fax: (305)284-4800. E-mail: q.kang@miami.edu.

${ }^{\ddagger}$ Corresponding author. School of Economics and Finance, University of Hong Kong, Pokfulam, Hong Kong. Phone: (852)2859 1059. Fax: (852)2548 1152. E-mail: qliu@hku.hk.

${ }^{\S}$ Peter J. Tobin College of Business, St. John's University, Jamaica, NY 11439. Phone: (718) 990-7320. E-mail: qir@stjohns.edu.
} 


\title{
The Sarbanes-Oxley Act and Corporate Investment: A Structural Assessment
}

\begin{abstract}
We assess the impact of the Sarbanes-Oxley Act of 2002 on corporate investment in an investment Euler equation framework, where a dummy for the passage of the Act is allowed to affect the rate at which managers discount future investment payoffs. Using generalized method of moments estimators, we find that the rate U.S. firm managers apply to discount investment projects rises significantly after 2002, while the discount rate for U.K. firms remains unchanged. The effects of the legislation on corporate investment are asymmetric, and are much more significant among relatively small firms. We also find that well-governed firms, firms with a credit rating, and accelerated filers of Section 404 of the Act have become more cautious about investment.
\end{abstract}

JEL Classification: G18, G31, G34, K22, E22

Keywords: Sarbanes-Oxley Act, investment Euler equation, investment-implied discount rate, corporate governance 


\section{Introduction}

The Sarbanes-Oxley Act of 2002 (SOX hereafter) was enacted in an attempt to strengthen corporate governance of publicly listed firms and to restore investor confidence in U.S. capital markets. This legislation has triggered a fierce debate on its net effects on capital markets and the real economy. Critics question whether SOX, a consequence of the public's need for action in response to corporate scandals, strikes the right balance between costs and benefits. In particular, they are concerned about high compliance costs and the unintended consequences of one-size-fits-all SOX regulations. Research examining the economic effects of SOX finds mixed evidence. ${ }^{1}$ Most prior research focuses on examination of stock and bond market reactions to SOX-related events and changes in U.S. firms' accounting practices after the passage of this legislation, even though it is generally believed that the economic effects of the Act are more involved. The effects of SOX on the real economy have been little noted.

In this paper, we use an investment Euler equation framework to examine whether SOX has had a significant effect on U.S. firms' investment behavior. Our motivations for this inquiry are two-fold. First, understanding how regulations affect corporate investment is important and has widespread interest. For example, financial economists are interested in how regulations that aim to improve corporate governance really affect managerial decisions and real activities; accountants are concerned about the effects of new rules on information disclosure and financial reporting; and macroeconomists and policy makers are interested in the overall effects of legislation and other regulatory reforms on economic growth. We contribute to this line of research by explicitly examining the effects of SOX on U.S. firms' investment.

Second, extant studies rely largely on an event-study approach and reduced-form regressions. However, judging the net effects of SOX from market reactions to SOX-related events could be problematic as a stream of events led to the passage of SOX, and it is inherently difficult to

\footnotetext{
${ }^{1}$ Chhaochharia and Grinstein (2007) find that announcements of SOX regulations have significantly positive effects on firm value, and these effects are more significant for less compliant firms (also see Li, Pincus, and Rego, 2008). Zhang (2007), however, finds significantly negative market reactions to SOX-related events. Empirical studies that provide additional evidence in favor of SOX include Linck, Netter, and Yang (2008) (on board structure); Cohen, Dey, and Lys (2006) (on earnings management); and Heron and Lie (2006) and Narayanan and Seyhun (2008) (on opportunistic timing of option grants). Empirical studies that provide additional evidence against SOX include DeFond et al. (2007) (on bond market reactions to SOX-related events); Li (2006) and Litvak (2007) (on cross-listed foreign firms); Piotroski and Srinivasan (2008) (on the shift of firms' listing preference after SOX); and Leuz, Triantis, and Wang (2008) (on firms' going-dark transactions).
} 
specify precise event dates or to effectively control for contemporaneous factors. Drawing clean inferences from reduced-form regressions is difficult too, since these studies are unavoidably plagued by endogeneity. Estimation of a structural model of corporate investment is one way to avoid these pitfalls. In addition, in our structural setting, the effects of SOX on investment are readily captured by a change in the rate firm managers use to discount future investment payoffs, making it possible to measure the effects of SOX in an intuitive way.

We begin by constructing a standard intertemporal investment model that characterizes the investment allocation of a utility-maximizing firm manager. The manager maximizes utility by choosing how much income to consume and how much income to invest in each period. Dividend consumption is constrained by the firm's profit function and the manager's investment decision. The manager chooses the optimal level of investment so as to be indifferent between investing today and investing tomorrow. The model produces results in terms of intertemporal investment substitution where the stochastic discount factor is related to the manager's risk preference a lower discount factor (a higher discount rate) corresponds to a more cautious attitude toward corporate investment. The model allows managers' discount rate to vary across pre- and post-SOX periods. We conjecture and find that the rate managers use to guide their investment decisions rises significantly after SOX; further, the effects of SOX vary considerably by both firm size and the quality of corporate governance practices.

The intuition for using an investment Euler equation to assess how SOX affects corporate investment is easiest to see in a simple two-period example. When a firm manager considers investing today versus tomorrow, he has to consider the costs and benefits of this decision. Investing today entails a cost today; if investing tomorrow, he postpones the cost until later and thereby reduces this cost in terms of its present value. However, he also forgoes the marginal product of capital for one period. An investment Euler equation is simply a first-order condition that equates the marginal cost of investing today and the expected discounted cost of investing tomorrow. In this setting, the discount rate characterizes the manager's degree of willingness to invest. If the manager becomes more cautious or less willing to embark on new and risky projects, this caution will be reflected as an increase in the discount rate. Therefore, all else equal, an increase in the discount rate after the passage of SOX would reflect greater managerial caution in the new regulatory environment. 
Our model formalizes this intuition. The Euler equation governs the manager's decision on how much to invest. The Markovian nature of our model reduces the manager's infinite-horizon dynamic problem to an optimality condition concerning investment this period versus next period. The dynamic effects of SOX on investment are then captured by changes in the stochastic discount factor in the post-SOX period. It is thus possible to identify its effects from the time-series and crosssectional variation in corporate investment. Further, after controlling for a measure of investment opportunity (i.e., capital productivity), we can identify whether variations in investment in one period versus another period are caused by changes in the stochastic discount rate or changes in productivity, which alleviates the endogeneity concerns that arise in a reduced-form regression framework.

We estimate our investment Euler equation using a generalized method of moments (GMM) estimator. A key advantage of this approach is that it avoids sample selection, simultaneity, and measurement error biases via structural estimation with a large data set. To further separate the effects of SOX from the effects of other contemporaneous factors, we also examine a set of U.K. firms not affected by SOX, which provides an extra source of variation.

We parameterize the stochastic discount factor as a linear function of firm-specific characteristics: stock beta, firm size, book-to-market equity, and the past year's stock performance, all known to relate to the discount rate. We include in the parameterization a dummy variable equal to one in the post-SOX period and zero otherwise. The estimated coefficient on the dummy variable then characterizes the effects of SOX on corporate investment. We expect the estimated coefficient to be negative if firm managers become more cautious and start to care more about avoiding lawsuits and protecting reputation than about growing the firm and improving profitability in the post-SOX period. This tendency would be induced by reduced managerial discretion, greater regulatory and public scrutiny, higher compliance costs, a higher likelihood of litigation-based penalties, and greater constraints imposed by boards of directors.

The estimates of our model yield several principal findings. First, we find that the inferred discount rate of U.S. firms increased significantly after the passage of SOX, while the discount rate of U.K. firms remained virtually unchanged. Therefore, U.S. firm managers have become more cautious about investment post-SOX. This finding is consistent with results documented in Bargeron, Lehn, and Zutter (2009), who use a reduced-form regression approach in their empirical 
analysis.

Second, when we look only at U.S. firms, we find stronger effects of SOX on corporate investment among smaller firms, and firms with higher systematic risk. The firm size effect is not a surprise. Engel, Hayes, and Wang ( 2007) and Chhaochharia and Grinstein (2007) have both demonstrated in different contexts that SOX has a more significant impact on small firms. And Gao, Wu, and Zimmerman (2009) find that relatively smaller firms (those with a market capitalization of less than $\$ 150$ million) undertook less investment, paid more dividends, and repurchased more shares after SOX.

Third, in further support of the heterogeneous effects of SOX on corporate investment, we divide our U.S. sample into various subsamples according to firms' corporate governance performance, whether they have a credit rating, and whether their compliance with SOX was deferred. We find more pronounced effects for firms with better corporate governance and for firms with a credit rating. We also find stronger SOX effects for firms that were immediately subject to the regulations (firms classified as accelerated filers of Section 404) than for non-accelerated filers that were able to postpone their compliance. These results, obtained using a completely different analytical framework than prior work, lend some support to extant findings. For example, Li (2006) documents that better-governed cross-listed foreign firms are more sensitive to SOX and suffer more value loss upon its passage.

While our empirical approach has several advantages, it has a notable caveat. Estimation of our structural model indicates that larger firms tend to use a higher discount rate than smaller firms. This result is inconsistent with the finding in empirical asset pricing literature that smaller firms in general have higher expected stock returns. One potential explanation for this difference is that the discount rate in our setting is inferred from corporate investment, and hence it may exhibit a size effect that is different from that of stock returns. Nevertheless, how investment-based returns are related to stock returns is an important and wide-open area for future research.

Overall, we contribute to the debate over the net effects of SOX by showing that the SarbanesOxley Act has profoundly affected managerial investment decisions. While our structural estimation provides evidence that U.S. firms have become more cautious about investment in the post-SOX period, we do not address the broader question whether this caution is socially beneficial. We also contribute to the investment Euler equation literature (see, e.g., Whited, 1992; Love, 2003; Chirinko 
and Schaller, 2004; and Whited and Wu, 2006) and to the investment-based asset pricing literature, which explains the cross-section of expected stock returns or costs of equity from the perspective of value-maximizing firms (see, e.g., Cochrane, 1991; Berk, Green, and Naik, 1999; Zhang, 2005; and Liu, Whited, and Zhang, 2007). Liu, Whited, and Zhang (2007) use investment Euler equations to derive cross-sectional expected stock returns, which are essentially levered investment returns tied to firm characteristics. Our use of investment Euler equations focuses instead on the effects of legislation on corporate investment via the discount rates perceived by firm managers, that is, the effects of government regulation on real activities via changing managerial incentives.

The remainder of the paper proceeds as follows. In Section 2, we derive an investment Euler equation from a dynamic model of corporate investment for a utility-maximizing firm manager. This section details our estimation method, and states the hypotheses to be tested in terms of the model's parameters. Section 3 describes the data and the construction of the sample. Section 4 presents the empirical results, and Section 5 concludes.

\section{Model and Empirical Framework}

To motivate our empirical work and provide guidance for the choice of control variables in the estimation, we offer a simple partial-equilibrium model in which a firm manager maximizes expected utility by choosing investment and consumption. We derive our investment Euler equation from this simple model. ${ }^{2}$ We then outline the framework for our empirical analysis.

\subsection{A Simple Model}

Consider an infinitely lived firm $i$ that uses capital to produce goods in each period $t$. The firm manager maximizes the expected present discounted value of its utility over an infinite horizon given by

$$
V_{i 0}=E_{i 0}\left[\sum_{t}^{\infty} \beta u\left(d_{i t}\right)\right],
$$

where $E_{i 0}$ is the expectations operator conditional on firm $i$ manager's time zero information set; $\beta$ is the one-period discount factor common to all firms; $u($.$) is the manager's utility function (if$

\footnotetext{
${ }^{2}$ We are grateful to a referee for suggesting this model and its ensuing insight.
} 
the manager is risk-averse, the utility function is concave); and $d_{i t}$ is the dividend paid by firm $i$ in period $t$.

The manager maximizes Equation (1) subject to two conditions. The first defines dividends,

$$
d_{i t}=\Pi\left(K_{i t}, \zeta_{i t}\right)-C\left(I_{i t}, K_{i t}\right)-I_{i t}
$$

where $K_{i t}$ is the beginning-of-period capital stock; $\zeta_{i t}$ is a shock to the profit function that follows a Markov process and is observed by the firm at time $t$; $\Pi\left(K_{i t}, \zeta_{i t}\right)$ is the firm's profit function with $\Pi_{K} \equiv \frac{\partial \Pi}{\partial K}>0 ; I_{i t}$ is investment during time t; and $C\left(I_{i t}, K_{i t}\right)$ is the real cost of adjusting the capital stock, with $\frac{\partial C}{\partial I}>0, \frac{\partial C}{\partial K}<0$, and $\frac{\partial^{2} C}{\partial I^{2}}>0$.

The second identity characterizes capital stock accumulation,

$$
K_{i t+1}=\left(1-\delta_{i}\right) K_{i t}+I_{i t}
$$

where $\delta_{i}$ is the firm-specific constant rate of economic depreciation.

The choice variables in this model are $I_{i t}$ and $d_{i t}$, and the state variable is $K_{i t}$. Solving the model yields the Euler condition for $K_{i t}$ :

$$
1+\left(\frac{\partial C}{\partial I}\right)_{i t}=E_{i t}\left[\beta \frac{u^{\prime}\left(d_{i t+1}\right)}{u^{\prime}\left(d_{i t}\right)}\left\{\left(\frac{\partial \Pi}{\partial K}\right)_{i t+1}-\left(\frac{\partial C}{\partial K}\right)_{i t+1}+\left(1-\delta_{i}\right)\left(1+\left(\frac{\partial C}{\partial I}\right)_{i t+1}\right)\right\}\right]
$$

where $\frac{\partial C}{\partial I}$ is the marginal adjustment cost of investment; the term $\beta \frac{u^{\prime}\left(d_{i t+1}\right)}{u^{\prime}\left(d_{i t}\right)}$ is the marginal rate of substitution of dividends, or the pricing kernel from a consumption-based asset pricing model; and $\frac{\partial \Pi}{\partial K}$ is the marginal profit of capital.

For notational convenience, we define $\Gamma_{i t+1} \equiv \beta \frac{u^{\prime}\left(d_{i t+1}\right)}{u^{\prime}\left(d_{i t}\right)}$. We can then immediately rewrite Equation (4) as follows:

$$
1+\left(\frac{\partial C}{\partial I}\right)_{i t}=E_{i t}\left[\Gamma_{i t+1}\left\{\left(\frac{\partial \Pi}{\partial K}\right)_{i t+1}-\left(\frac{\partial C}{\partial K}\right)_{i t+1}+\left(1-\delta_{i}\right)\left(1+\left(\frac{\partial C}{\partial I}\right)_{i t+1}\right)\right\}\right] .
$$

The Euler equation in Equation (5) describes the evolution of the firm manager's investment decisions along the optimal path and has an intuitive interpretation. To decide whether to invest in the current period versus in the next period, a manager must consider the costs and benefits 
of the timing decision. This equation is simply a first-order condition that describes the optimal intertemporal allocation of investment. The left-hand side represents the marginal adjustment cost of investing in this period. The right-hand side represents the expected discounted cost of waiting to invest until next period, which consists of the marginal product of capital and the marginal reduction in adjustment costs from an increment to the capital stock. Even if the firm waits, it still incurs adjustment costs. Deciding investment optimally necessitates that, on the margin, the manager must be indifferent between investing in the current period and transferring those resources to the next period.

The factor $\Gamma_{i t+1}$ in Equation (5) merits further discussion. By construction, $\Gamma_{i t+1}$ is the product of the discount factor common to all firms $(\beta)$ and the ratio of the marginal utility of dividends in the next period to the marginal utility of dividends in the current period. Because our investment Euler equation characterizes the optimal intertemporal allocation of investment, $\Gamma_{i t+1}$ is essentially the discount factor that the firm manager uses to discount the investment returns in the next period. While $\Gamma_{i t+1}$ is clearly related to the manager's preferences, it can be interpreted as the stochastic discount factor of the dynamic utility optimization problem that guides the manager's optimal investment choices. We can accordingly define the stochastic discount rate $r_{i t}$ as

$$
r_{i t}=\frac{1}{\Gamma_{i t}}-1
$$

where $r_{i t}$ can be interpreted as the "perceived" hurdle rate the firm manager uses for optimal investment.

If the firm manager is risk-averse and dividend growth is positive, greater managerial risk aversion implies a higher discount rate (a lower discount factor). This intuition can be best illustrated in the following way (also see Cochrane, 2001, pp. 13-14). Under a CARA utility function $u\left(d_{t}\right)=\frac{d_{t}^{1-\gamma}}{1-\gamma}, \Gamma_{i t+1}=\beta\left(\Delta d_{t+1}\right)^{-\gamma}$, where $\beta$ is the manager's subjective discount rate (a higher $\beta$ indicates a higher level of patience); $\Delta d_{t+1} \equiv \frac{d_{t+1}}{d_{t}}$ measures the gross dividend growth rate; and the curvature parameter $\gamma$ measures the manager's aversion to risk (a higher $\gamma$ indicates a higher level of risk aversion). If the manager becomes less patient (i.e., $\beta$ declines) or more riskaverse (i.e., $\gamma$ increases), then all else equal we expect a lower discount factor $\Gamma$, or equivalently, a higher investment hurdle rate $r$. Conversely, if the dividend growth rate remains positive and 
$r$ increases, we can infer that the manager has become either less patient or more risk-averse. Clearly, if we hold the manager's patience constant, greater managerial risk aversion implies a higher discount rate, and vice versa.

\subsection{Estimation}

To estimate the model, we replace the expectations operator in Equation (5) with an expectational error, $e_{i t+1}$, such that $E_{i t}\left(e_{i t+1}\right)=0$ and $E_{i t}\left(e_{i t+1}^{2}\right)=\sigma_{i t}^{2}$. The first condition suggests that $e_{i t+1}$ is uncorrelated with information available at time $t$, and the second implies that the expectational error can be heteroskedastic. We thus rewrite Equation (5) as

$$
\Gamma_{i t+1}\left\{\left(\frac{\partial \Pi}{\partial K}\right)_{i t+1}-\left(\frac{\partial C}{\partial K}\right)_{i t+1}+\left(1-\delta_{i}\right)\left(1+\left(\frac{\partial C}{\partial I}\right)_{i t+1}\right)\right\}=1+\left(\frac{\partial C}{\partial I}\right)_{i t}+e_{i t+1}
$$

To parameterize the marginal product of capital, we follow Whited (1998) and Whited and $\mathrm{Wu}(2006)$ and assume that firms are imperfectly competitive. We thus set the output price as a constant mark-up, $\mu$, over the marginal cost. In this case, constant returns to scale implies

$$
\frac{\partial \Pi}{\partial K}\left(K_{i t}, \zeta_{i t}\right)=\frac{Y_{i t}-\mu V C_{i t}}{K_{i t}},
$$

where $Y_{i t}$ is output; $\mu$ is the markup; $V C_{i t}$ is variable cost; and $K_{i t}$ is capital stock.

We parameterize the adjustment-cost function, $C\left(I_{i t}, K_{i t}\right)$, as follows (see Whited (1998) for details):

$$
C\left(I_{i t}, K_{i t}\right)=\left(\sum_{m=2}^{M} \frac{1}{m} \alpha_{m}\left(\frac{I_{i t}}{K_{i t}}\right)^{m}\right) K_{i t},
$$

where $\alpha_{m}, m=2, \ldots, M$ are coefficients to be estimated and $M$ is a truncation parameter that sets the highest power of $\frac{I_{i t}}{K_{i t}}$ in the expansion. We follow Whited and Wu (2006) and set $M=3$.

Substituting Equation (8) into Equation (7), differentiating Equation (9) with respect to $I_{i t}$ and $K_{i t}$, and substituting the derivatives into Equation (7), we obtain the following equation:

$$
\begin{array}{r}
\Gamma_{i t+1}\left\{\frac{Y_{i t+1}-\mu V C_{i t+1}}{K_{i t+1}}+\sum_{m=2}^{M} \frac{m-1}{m} \alpha_{m}\left(\frac{I_{i t+1}}{K_{i t+1}}\right)^{m}+\left(1-\delta_{i}\right)\left(1+\sum_{m=2}^{M} \alpha_{m}\left(\frac{I_{i t+1}}{K_{i t+1}}\right)^{m-1}\right)\right\} \\
=1+\sum_{m=2}^{M} \alpha_{m}\left(\frac{I_{i t}}{K_{i t}}\right)^{m-1}+e_{i t+1} .
\end{array}
$$


To estimate Equation (10), we need to specify the stochastic discount factor, $\Gamma_{i t+1}$. One possibility would be to use a consumption-based pricing kernel to demonstrate the theoretic linkage between managerial risk preferences and stochastic discount rates. Consumption-based asset pricing models, however, are known to perform poorly in empirical studies. The same is true in our case; estimating the above investment Euler equation with a consumption-based pricing kernel yields disappointing empirical results. ${ }^{3}$

As Cochrane (2001) argues, all asset pricing models amount to different ways of connecting the stochastic discount factor to data. There are many possible structural or reduced-form parametrizations, expressing the stochastic discount factor as functions of state variables such as consumption growth, aggregate wealth proxies, or data-driven factors. Opting for a reducedform specification, we specify $\Gamma_{i t}$ as a function of several firm-level characteristics that have been shown to be related to the discount factor (see, e.g., Fama and French, 1992; Jegadeesh and Titman, 1993) and a SOX dummy variable, which takes the value of one in the post-SOX period and zero otherwise: ${ }^{4}$

$$
\Gamma_{i t}=l_{0}+l_{1} \beta_{i t}+l_{2} \text { size }_{i t}+l_{3} \text { btm }_{i t}+l_{4} \text { annret }_{i t}+l_{5} D S O X_{t} .
$$

Here, $\beta_{i t}$ is calculated according to the capital asset pricing model (CAPM) using the previous five years of monthly stock returns and market returns. It measures the systematic risk to which a firm is exposed. The variable size $i t$ measures firm size and is computed as the logarithm of a firm's year-end market capitalization; $b t m_{i t}$ is defined as the book-to-market equity of firm $i$ in year $t$; annret $t_{i t}$ is the past 12-month cumulative stock return for firm $i$, which captures stock return momentum; and $D S O X_{t}$ is the SOX dummy variable.

An ad hoc parameterization of the stochastic discount factor provides empirical flexibility. For example, we include $D S O X$ as one determinant, which translates the potential effects of SOX on investment into changes in the stochastic discount factor in the post-SOX period. This approach works at least as well as, if not better than, some structural specifications of the stochastic discount

\footnotetext{
${ }^{3}$ When we parameterize the stochastic discount factor $\Gamma_{i t}$ as a linear function of aggregate consumption growth, we find that all models perform quite poorly, in the sense that the overidentifying restrictions are soundly rejected in all cases.

${ }^{4}$ Equation (11) is the baseline specification of the discount factor function in our empirical tests. More discount factor specifications will be introduced in Section 4.
} 
factor (see, e.g., Whited, 1992; Love, 2003; and Whited and Wu, 2006).

Several issues arise in the reduced-form specification of the stochastic discount factor. First, the parameterization in Equation (11) does not allow for an explicit error term; the specification could be incorrect. We test this assumption using $J$-test statistics of the overidentifying restrictions, which provide an important check on the model's validity. Second, the structural model provides no guidance on which variables should be included in the parameterization of the stochastic discount factor. While the specification is flexible enough to account for any relevant variables that may determine the discount factor, we find that the four variables in Equation (11) work well in most cases, as measured by the $J$-test statistics. We also experiment with dropping variables with less statistical significance, starting with the four variables in Equation (11), and examine the difference between the two minimized GMM objective functions for the general model and the subsequently less general model. The difference asymptotically follows a $\chi^{2}$ distribution with degrees of freedom equal to the number of variables dropped from the more general model. If a variable belongs in the parameterization of the stochastic discount factor, its omission should produce a low $p$-value. We use Whited and Wu's (2006) notation of L-test to describe this test of exclusion restrictions. We find that we can eliminate the variable capturing the previous year's stock return with little effect on model performance.

We estimate Equation (10), with $\Gamma_{i t+1}$ parameterized as in Equation (11), in first differences in order to eliminate possible fixed firm effects. We apply GMM to the moment conditions

$$
E_{t-1}\left[z_{i t-1} \otimes\left(e_{i t+1}-e_{i t}\right)\right]
$$

where $z_{i t-1}$ is a vector of instrumental variables known at time $t$, and $\otimes$ denotes the Kronecker product. Because this estimator is implemented in first differences, the procedure calls for using variables dated $t-2$ as instruments. We thus use as instruments the two-period-lagged variables that include all the variables that appear in our investment Euler equation and several firm-specific variables.

The intuition behind using changes in the stochastic discount rate to identify the effects of SOX on investment warrants further discussion. First, as this empirical strategy allows us to control for changes in investment opportunities, the effects of SOX on investment can be separated from the 
effects of other contemporaneous factors. The SOX effects in our setting can also be characterized by changes in the discount rate, which is an appealing feature. Second, because of the Markovian nature of our model, the Euler equation governs the manager's decision to invest now rather than in the next period. Hence, SOX effects, if any, have already been incorporated in the optimal investment at time $t$ and have no direct effect on the decision to invest now versus later. Once the problem is reduced to a marginal condition over two periods, the time-series variation in investment enables us to identify the SOX effects through changes in the discount rate.

\subsection{Linking Model to Hypotheses}

We believe the Sarbanes-Oxley Act is likely to make the managers of U.S. firms more cautious in making investment for several reasons. First, SOX mandates extensive changes to improve the effectiveness of internal controls, auditor independence, and the quality of boards of directors (particularly audit committees). ${ }^{5}$ One potential consequence of these changes is a reduction in managerial discretion over corporate decisions. Second, since the passage of SOX, firm managers have become more accountable for decisions; in particular their personal liability is greatly increased. It is also likely that SOX exposes firm managers to increased scrutiny by the public and potential market rivals. Third, the new regulations impose high compliance costs on firms and may divert managerial attention from business-related duties toward SOX-compliance activities. A preoccupation with compliance may discourage managers from taking business risks.

In our empirical setting, the coefficient on DSOX characterizes the effects of the SarbanesOxley Act on the stochastic discount factor, and hence the effects of SOX on the implied hurdle rate perceived by managers when making investment decisions. We thus expect $l_{5}$ in Equation (11) to be negative. If it is significantly negative, we can conclude that the stochastic discount factor $\Gamma_{i t}$ dropped after SOX; the hurdle rate for managerial investment decisions rose; and managers became more cautious.

While our structural estimation strategy can control for investment opportunities and mitigate endogeneity, we include a U.K. firm sample in the analysis to better isolate the effects of SOX

\footnotetext{
${ }^{5}$ For example, Section 302 of the Act requires firm CEOs and CFOs to certify the veracity of firms' financial statements; Section 304 allows fraud to be penalized by requiring the return of incentive-based compensation and profits from stock sales in the event of earnings restatements; and Section 404 requires company managers and auditors to attest to the effectiveness of internal controls, which may strengthen management accountability in the preparation of financial reports.
} 
on U.S. firms. To accommodate the addition of U.K. firms, we modify our specifications of the discount factor. Using the dummy variable $D^{U S}$ to indicate the U.S. firms that are subject to the new regulations, the variable of interest becomes $D^{U S} \times D S O X-$ all else equal, we expect SOX to be relevant only for U.S. firms.

To examine how the effects of SOX vary with firm characteristics, we modify the parameterization of $\Gamma_{i t}$ by adding interaction terms to Equation (11). These terms are interactions between $D S O X$ and the firm characteristic variables.

\section{Data and Descriptive Statistics}

This section discusses our data sources and the construction of the samples. It next defines the variables used in the empirical analysis and offers their summary statistics.

\subsection{Data and Sample Construction}

The data for this study are annual, covering the period from 1998 to 2005, and come from several sources. For U.S. firms in the sample, accounting information comes from Standard \& Poor's Compustat Annual database. We retrieve stock price and stock return information from the Center for Research in Security Prices (CRSP) Monthly Stock File. After merging the Compustat and CRSP databases, we obtain an initial sample covering 9,453 unique U.S. publicly listed firms.

We apply several data filtering rules to obtain our final sample. We first delete any firm-year observations for which total assets, gross capital stock, or sales are either zero or negative. We also omit all firms that have primary SIC classifications between 4900 and 4999 or between 6000 and 6999, because our model is inappropriate for regulated or financial firms. This reduces the sample size to 7,527 unique companies. We then drop from the sample firms with missing data, which leaves us with 5,845 unique firms. We further exclude firms with extreme values, i.e., variable values that are higher than the 99th and lower than the 1st percentile, which reduced the sample size to 5,115 firms. Finally, we drop firms for which there are not three consecutive years of complete data. These screens leave us with an unbalanced panel of between 2,479 and 3,048 firms per year over the sample period.

We apply the same filtering procedures to the U.K. listed firms that serve as a comparison group. 
For those firms, accounting data are collected from the Compustat Global Industrial/Commercial File, and market capitalization and stock price information are obtained from the Compustat Global Issue database. Monthly stock returns over the sample period are computed using end-of-month adjusted stock prices. The initial U.K. sample consists of 1,642 unique firms. After dropping firms in financial services and utilities, we are left with 1,360 firms. Excluding firms with missing or extreme values reduces the sample size to 1,072. Finally, we exclude firms for which there are not three consecutive years of complete data, yielding an unbalanced panel of between 387 and 707 firms for each year of the sample period.

To facilitate analysis of how the effects of SOX on corporate investment depend on corporate governance, we also create subsamples of well-governed and poorly governed firms. For this purpose, we use the governance index (G-index) compiled by Gompers, Ishii, and Metrick (2003), who examine indicators for 24 governance provisions to construct an index that proxies for the level of shareholder rights at approximately 1,500 large firms. Because data on the G-index are available only in alternate years, we extrapolate missing values by setting the missing value equal to the value of the index in the previous year. Because this index is a very noisy measure, we sort the firms into three equal-sized subgroups based on their G-Index values in each year, and then exclude the middle subgroup. The top and bottom groups include between 264 and 390 firms for each year of the sample period.

As a robustness check, we also construct these groups using Bebchuk, Cohen, and Ferrell's (2009) entrenchment index (E-index), which represents 6 out of the 24 provisions in the G-index, to measure the corporate governance quality of U.S. firms. Doing so results in top and bottom subgroups that include between 264 and 390 firms per sample year.

The third sorting variable we use is an indicator variable for whether a firm is rated by Standard \& Poor's. This information is extracted from the Compustat database (item 280). We then sort the U.S. firms into two subsamples depending on whether they have $\mathrm{S} \& \mathrm{P}$ credit ratings in the previous year. The first subsample, in which firms' credit ratings are available, consists of between 730 and 830 firms per sample year, and the second subsample consists of between 2,100 and 2,620 firms per sample year. 


\subsection{Variables}

We first define $D S O X$, which is a dummy variable that takes the value of one in 2003, 2004, and 2005, and zero otherwise. ${ }^{6}$ Throughout the analysis, estimated parameters on DSOX capture the effects of SOX on corporate investment.

All monetary variables in the empirical analysis are in 1998 constant U.S. dollars. The key variable for the empirical analysis is corporate investment, $I_{i t}$, which is defined as: ${ }^{7}$

$$
I_{i t}=C A P E X_{i t}-S a l e P P E_{i t},
$$

where $C A P E X_{i t}$ is capital expenditure in year $t$ for firm $i$ (Compustat item 30 for U.S. firms and item 193 for U.K. firms) and SalePPE $E_{i t}$ is sales of property, plant, and equipment (item 107 for U.S. firms and item 181 for U.K. firms). ${ }^{8}$ We measure the capital stock by beginning-of-year total assets (item 6 for U.S. firms and item 89 for U.K. firms), Asset ${ }_{i t-1}$, and use it to deflate other variables, thereby reducing heteroskedasticity in normalized firm-level variables. We divide $I_{i t}$ by Asset $_{\text {it-1 }}$ to obtain the investment-to-capital ratio. Annual averages of the investment-to-capital ratio over the sample period are reported in Table 1.

Panel A shows that the mean ratio for U.S. firms declines from 0.081 in 1998 to 0.055 in 2005. A quick comparison of the average pre- and post-SOX ratios (between 1998-2002 and 2003-2005) seems to suggest that corporate investment declined significantly for U.S. firms after the passage of the Act. Panel B reports the mean investment-to-capital ratio for the U.K. sample, where a similar decline is observed. Note that such a simple comparison fails to account for changes in investment opportunities.

We measure firm $i$ 's output in year $t$ by its sales, Sale $e_{i t}$ Variable cost, $V C_{i t}$, is the sum of the costs of goods sold and selling, general, and administrative expenses. We divide both Sale $_{i t}$

\footnotetext{
${ }^{6}$ For GMM estimations, we use investment Euler equation variables lagged by two periods as instruments. Therefore, we conduct our structural estimation for the 2000-2005 period, where 2000, 2001, and 2002 are the pre-SOX period and 2003, 2004, and 2005 are the post-SOX period. We obtain similar results when we include 2002 in the post-SOX period.

${ }^{7}$ We do not include expenditures on acquisition activities (item 129 for U.S. firms) because acquisitions are lumpy expenditures, and an investment Euler equation in a model with smooth adjustment costs cannot characterize such expenditures on acquisitions (Abel and Eberly, 1994; Whited, 2006).

${ }^{8}$ In unreported analysis, we define another measure of investment, $I R_{i t}$, which is the sum of $I_{i t}$ and research and development expenses. This measure yields empirical results that are similar. These results are available from the authors upon request.
} 
and $V C_{i t}$ by beginning-of-year total assets. We estimate $\beta$ by fitting the CAPM on a rolling basis with monthly stock returns over the previous five years. For U.S. firms, we measure the market return $\left(r_{m}\right)$ and the risk-free rate $\left(r_{f}\right)$ by the CRSP value-weighted market index return and by the one-month Treasury bill rate; for U.K. firms, we measure the market return and the risk-free rate by the MSCI U.K. index return and by the 91-day Treasury bill yield. Total stock return volatility (annvol) is the annualized standard deviation of monthly stock returns over the past five years. ${ }^{9}$ Note in Panel A of Table 1 that $\beta$ increases significantly after the passage of SOX for U.S. firms. This pattern is even more marked for U.K. firms. We do not observe a significant change in annualized stock volatility (annvol) for either U.S. or U.K. firms post-SOX.

For both U.S. and U.K. firms, we calculate firm size (size) as the logarithm of the year-end market value of the firm's common equity. Book-to-market equity $(\mathrm{btm})$ is the book value of the firm's equity divided by its market value of common equity. We also calculate the cumulative stock return over the previous 12 months (annret). Finally, to proxy for a firm's debt ratio, we define leverage as the ratio of the book value of the firm's debts to its total assets. Table 1 shows that firms became larger in the post-SOX period in the U.S. sample, but that this trend was less pronounced for U.K. firms. Book-to-market equity declined significantly for both U.S. and U.K. firms over time. The average leverage ratio also dropped in the post-SOX period for U.S. firms, but it remained largely unchanged for U.K. firms.

GMM estimation requires use of instrumental variables. To balance validity and parsimony in the selection of instruments, we choose instrumental variables that are a priori the most relevant to corporate investment decisions. For most of the GMM estimates, we use the following 11 instruments: $r_{f}, \frac{Y}{K}, \frac{I}{K}, \frac{V C}{K}, \beta$, size, btm, annret, annvol, leverage, and a constant. All but the constant are lagged by two periods.

\footnotetext{
${ }^{9}$ Ang et al. $(2006,2009)$ report robust evidence that stock return volatility is related to cross-sectional variation in average returns in both U.S. and international equity markets. We have experimented with including annvol as an additional determinant of the stochastic discount factor, but the results of model specification tests suggest that annvol does not belong in the set of firm-level variables that parameterize the stochastic discount factor. We use annvol, lagged by two periods, as an instrument in our GMM estimation.
} 


\section{Empirical Results}

This section presents estimates of our GMM estimation for the pooled sample consisting of both U.S. and U.K. firms, the U.S.-only sample, and the U.K.-only sample. It next offers results of cross-sectional analysis. It concludes by discussing estimates based on several subsamples, which further demonstrate heterogeneous effects of SOX on corporate investment.

\subsection{GMM Results for the Pooled Sample}

We first use GMM to estimate parameters of the discount factor function for the pooled sample of U.S. and U.K. firms. Because SOX applies to all publicly listed U.S. firms (with some exemptions for certain small firms), U.K. firms are used to provide additional variation to better identify the effects of SOX. The discount factor function is specified as:

$$
\begin{aligned}
\Gamma_{i t}= & l_{0}+l_{1} \beta_{i t}+l_{2} \text { size }_{i t}+l_{3} \text { btm }_{i t}+l_{4} \text { annret }_{i t}+l_{5} S O X_{t}+l_{6} D^{U S}+l_{7} D^{U S} \times D S O X_{t} \\
& +l_{8} D^{U S} \times \beta_{i t}+l_{9} D^{U S} \times \text { size }_{i t}+l_{10} D^{U S} \times \text { btm }_{i t}+l_{11} D^{U S} \times \text { annret }_{i t},
\end{aligned}
$$

where $D^{U S}$ is an indicator that takes the value of one if a firm is a U.S. firm and zero otherwise. For the pooled sample, the key coefficient of interest is $l_{7}$, which captures how the discount rates for U.S. firms change after SOX compared to U.K. firms. Besides the 11 instrumental variables mentioned previously, we also include as additional instruments the dummy variable $D^{U S}$, its interactions with $\beta$, size, btm, and annret (each lagged by two periods), and the interaction between $D^{U S}$ and $D S O X$. This results in a total of 17 instruments.

Table 2 presents the results of estimating the model given by Equations (10) and (14). Note that of the four models, J-tests of overidentifying restrictions do not reject these restrictions except for the model in Column 4. This finding is particularly important in light of the deterministic specification of Equation (14). If this equation were to have an error term, the covariance between this error term and the remainder of the left side of Equation (10) would be implicitly included in $e_{i t+1}$, and would violate the overidentifying restrictions (see Whited and $\mathrm{Wu}$ (2006) for details).

The results of the most general model, where firm size, $\beta$, book-to-market, and the previous year's return are used to parameterize the stochastic discount factor, are reported in Column 1 of 
Table $2 .{ }^{10}$ The estimate of the parameter of interest, $l_{7}$, is -0.066 , significant at the $10 \%$ level. This suggests that all else equal, U.S. firms tend to have lower discount factors (higher discount rates) than U.K. firms in the post-SOX period. The estimated coefficients on annret, its interaction with the U.S. dummy $D^{U S}$, and the interaction of $\beta$ with $D^{U S}$ are not significantly different from zero.

Column 2 presents estimates from a model that eliminates annret and its interaction with $D^{U S}$ in parameterization of the discount factor. Whited and Wu's (2006) L-test suggests that dropping these variables should not affect the performance of the model. In this specification, $l_{7}$ is estimated to be -0.069 , significant at the $5 \%$ level. In Column $3, \beta$ and its interaction with $D^{U S}$ are also dropped. In this case, the exclusion restrictions concerning $\beta$ and its interaction with $D^{U S}$ are rejected. Even so, in this model the estimated coefficient on the interaction term $D^{U S} \times D S O X$ remains negative at -0.064 , which is marginally significant at the $10 \%$ level. As the model in Column 2 has the best overall performance, we treat it as the benchmark model for analysis of the pooled sample.

The other results in Column 2 are instructive too. The estimated coefficient on DSOX is insignificant. The estimated coefficient on $D^{U S}$ is significantly negative, suggesting that U.S. firm managers perceive a lower discount factor, or a higher discount rate, than U.K. managers over our sample period. This result, combined with the significantly negative coefficient on the interaction term $D^{U S} \times D S O X$, implies that U.S. firms use higher discount rates when making investment decisions than U.K. firms in the post-SOX period.

It is puzzling that the estimated coefficients on size and the interaction term size $\times D^{U S}$ are significantly negative and positive respectively, indicating that larger firms perceive a higher discount rate than smaller firms, but this is less true for U.S. firms than for U.K. firms. This unexpected result warrants more discussion, as it is inconsistent with conventional wisdom that smaller firms tend to have higher discount rates. We suspect the explanation is that because smaller firms are in general younger and grow faster, all else equal, they tend to use lower hurdle rates and invest more.

Discount rates in our setting are inferred from corporate investment using a structural

\footnotetext{
${ }^{10}$ We also experimented with more general models than the ones reported in Table 2. Those models include additional relevant firm-specific variables as determinants of the stochastic discount factor. These additional variables turn out to be statistically insignificant, and the model specification tests suggest they should be excluded from the parameterization of the stochastic discount factor. A practical problem in using so many variables is that we then need more instrumental variables, which greatly reduces the stability of estimation results.
} 
estimation. They are investment-based expected stock returns, and they may exhibit a size effect that is different from the size effect based on stock returns. How to reconcile differences in investment-based returns and stock market-based returns is an interesting question left to future research (for efforts on this front, see Zhang 2005; and Liu, Whited, and Zhang 2007).

The estimated coefficient on $\beta$ is significantly negative, and the interactive term $\beta \times D^{U S}$ is significantly positive, indicating that riskier firms perceive higher discount rates, although this relation is weaker for U.S. firms than for U.K. firms. Finally, the coefficient estimates on btm and $b t m \times D^{U S}$ are both insignificant. The mark-up estimate, $\mu$, is positive and significantly larger than one, which is consistent with evidence in the investment Euler equation literature (Whited, 1998).

One notable observation is that the adjustment cost parameter estimates are significant only in certain model specifications in Table 2. A potential explanation is that it is difficult to identify the financial parameters and the adjustment cost parameters at the same time. Further, firms may react sluggishly to an investment, so a relatively short time period makes it difficult to obtain precise estimates of the adjustment cost parameters. In support of this explanation, we estimate an investment Euler equation without any financial variables over our sample period. In this case, the adjustment cost parameter estimates are significantly different from zero. This suggests that, in our setting, the variables that determine the stochastic discount factor are much more important for intertemporal capital allocation decisions than adjustment costs.

Finally, we formally test the hypothesis that U.S. firms and U.K. firms share the same investment policies in the post-SOX period. That is, we test that the impact on corporate investment for U.S. firms and U.K. firms is the same, and that $\beta$, size, and btm affect U.S. and U.K. firms' stochastic discount factors in the same way. Under this null hypothesis, the coefficients on the interactions of $D^{U S}$ with $D S O X, \beta$, size, and btm should all be zero. Column 4 of Table 2 reveals that this model performs quite poorly, it is strongly rejected by the $J$-test of overidentifying restrictions, suggesting that investment behavior of U.S. firms is distinctly different from U.K. firm behavior.

\subsection{U.S. Firms vs. U.K. Firms}

To further understand differences between the investment behavior of U.S. and U.K. firms, and to measure the economic effects of SOX on investment, we estimate models separately for the U.S. 
and U.K. samples. The results are in Table 3. The most general model in Table 3 is specified as in Equations (10) and (11). The key parameter of interest is $l_{5}$, the coefficient on DSOX.

Column 1 of Table 3 presents GMM results for the U.S. sample. The $J$-test of over-identifying restrictions fails to reject the model. The estimated coefficient on DSOX is negative at -0.104 and significant at the $10 \%$ level. This result reinforces our earlier finding that U.S. firms became more cautious about investment after the passage of SOX. Column 3 reports estimates of the same model for U.K. firms. Although the $J$-test still does not reject the model, the estimated coefficient on $D S O X$ is not statistically significant, suggesting that U.K. firms' investment behavior did not change significantly after SOX.

As in Table 2, we find that the estimated coefficient on annret is not significant in either sample. We thus drop this variable from our specification of the stochastic discount factor. Columns 2 and 4 report results for estimation of our investment Euler equation for the U.S. and U.K. samples. In both cases, the L-test of exclusion restrictions fails to reject the null hypothesis that annret should be excluded from the specification. We thus use the model in Columns 2 and 4 in the analysis henceforth.

In the U.S. sample, the estimated coefficient on $D S O X$ is significantly negative at -0.132 , suggesting that U.S. firms tend to use higher discount rates to evaluate future investment returns post-SOX. Estimated coefficients on size, btm, and $\beta$ are all negative, suggesting that large firms, value firms, and riskier firms (firms with a higher $\beta$ ) all tend to use higher discount rates. Column 4 presents estimates for the U.K. sample. The SOX dummy is insignificant, confirming our finding that the SOX effects on investment are confined to U.S. firms.

To gauge the economic extent of the effects of SOX on corporate investment, we estimate the perceived discount rates for each firm by plugging the relevant variable values into the stochastic discount factor equation, according to the specifications in Columns 2 and 4 of Table 3. We assume that the average discount rates for both U.S. and U.K. firms are $10 \%$ over $1998-2005 .{ }^{11}$ This assumption allows us to estimate the value of the constant term $l_{0}$ for both U.S. and U.K. firms, which is 1.917 for the U.S and 1.677 for the U.K. Based on the estimated coefficients, we compute the investment-based discount rate for each firm-year observation.

\footnotetext{
${ }^{11}$ The assumption is an innocuous one. Using different average discount rates would change the magnitude of the inferred discount rates, but it would not change the relative patterns in the dynamics of the inferred discount rates.
} 
Because the discount rates are inferred from the estimated discount factor equation and are tied to firm characteristics, there are many outliers. To better understand how SOX affects the investment behavior of average U.S. and U.K. firms, we eliminate observations with extreme discount rate values in our analysis. Specifically, in each year, we separately delete U.S. and U.K. firms with discount rates smaller than the 5th percentile or larger than the 95th percentile. For the remaining firms, we then separately calculate yearly averages for U.S. firms and U.K. firms. Figure 1 plots these yearly averages for the U.S. and U.K. In unreported analysis, we use yearly medians for U.S. and U.K. firms and find similar results.

As Figure 1 shows, the average discount rate of U.S. firms is relatively flat from 1998 through 2002, ranging from $7.9 \%$ to $10.2 \%$. After the passage of SOX, however, the average discount rate spikes up to $15.2 \%$ in $2003,16.5 \%$ in 2004 , and $16.6 \%$ in 2005 . The average discount rate for U.K. firms, in contrast, remains relatively stable over the entire sample period. This is exactly what we would expect to see if SOX had a strong effect on the investment decisions of U.S. firms, but only a mild effect (if any) on U.K. firms.

\subsection{Cross-Sectional Analysis}

Having established that U.S. firms responded very strongly to the passage of SOX, we examine how this response varies with firm characteristics. To answer this question, we extend the specification of $\Gamma_{i t}$ by adding a set of interactive terms between $D S O X_{t}$ and various firm-specific variables. The new specification is

$$
\Gamma_{i t}=l_{0}+l_{1} \beta_{i t}+l_{2} \text { size }_{i t}+l_{3} b t m_{i t}+l_{4} D S O X_{t}+l_{5} X_{i t} \times D S O X_{t},
$$

where $X$ represents a set of firm-specific variables such as $\beta$, size, and btm. ${ }^{12}$ The marginal effect of $D S O X$ on $\Gamma$ is thus given by

$$
\frac{\partial \Gamma_{i t}}{\partial D S O X_{t}}=l_{4}+l_{5} X_{i t}
$$

In Equation (16), the constant $l_{4}$ captures the effect of $D S O X$ on the stochastic discount factor that is unrelated to the firm-specific variables $X$, and $l_{5} \times X$ measures the effect of $S O X$ on the

\footnotetext{
${ }^{12}$ Since prior stock market performance (annret) is not a significant determinant of the discount factor in previous analysis, we do not consider this variable in the cross-sectional analysis.
} 
stochastic discount factor via $X$.

Estimation of our investment Euler equations for U.S. firms with the extended specification of the stochastic discount factor is given in Table 4. For ease of comparison, Column 1 of Table 4 reproduces the results in Column 2 of Table 3. In Column 2 of Table 4, we parameterize the stochastic discount factor by including the interaction of $D S O X$ with size. The $J$-test of overidentifying restrictions fails to reject the validity of this model, although the $L$-test of exclusion restrictions suggests that we should not include $D S O X \times$ size as a determinant. As for the parameter estimates, the coefficient on $D S O X$ remains significantly negative at -0.705 , and the coefficient on the interactive term is significantly positive at 0.113 . These results suggest that while both small firms and large firms have become more cautious about investment in the post-SOX period, the effects of SOX are more pronounced for smaller firms than for larger firms. A possible explanation is that SOX imposes a cost of compliance that is relatively high for small firms, forcing them to be more cautious about investment. As we have noted, this finding is consistent with prior findings in the literature.

In Column 3 of Table 4, we parameterize the stochastic discount factor by including the interaction between $D S O X$ and $b t m$. While the $J$-test does not reject the model, the $L$-test suggests that this interactive term should also be excluded from the discount factor. Still, the parameter estimates reveal an interesting finding. The estimated coefficient on $D S O X$ is significantly negative at 0.747 , and the estimated coefficient on btm $\times D S O X$ is positive, although not statistically significant, at 0.447. This implies that, all else equal, growth firms (firms with low btm) appear to be more cautious than value firms (firms with high btm) when making investment after SOX. This interpretation should be taken with caution, however, because the estimated coefficient on the interactive term and the $L$-test suggest it should not be included in the model.

In Column 4 of Table 4 , we interact $D S O X$ with $\beta$ and include it in the parametrization of the discount factor. As in the first two cases, while the $J$-test of overidentifying restrictions does not reject the model, the $L$-test suggests we should not include this interactive term. The estimated coefficient on $D S O X$ is positive but insignificant. The estimated coefficient on the interaction is significantly negative, which indicates that riskier firms have become more cautious in the post-SOX period.

All in all, the results in Table 4 provide some evidence that U.S. firms have adjustee their 
investment decisions in response to the SOX regulations. In the U.S. sample, smaller firms, growth firms, and riskier firms all tend to use higher discount rates for post-SOX investment.

\subsection{Subsample Analysis}

Proponents of the Sarbanes-Oxley Act argue that its regulations are necessary to strengthen monitoring mechanisms and improve corporate governance in U.S. firms. Following this argument, we would conjecture that firms with poor corporate governance should be affected the most by the regulations. That is, in terms of making investment decisions, firms that are less compliant with SOX should be more responsive to the implementation of these provisions. To test this, we use several variables to measure the quality of firms' corporate governance. The first is the corporate governance index compiled by Gompers, Ishii, and Metrick (2003). A high G-index score indicates poor corporate governance practices at the firm level. Ceteris paribus, the provisions of the Sarbanes-Oxley Act impose more severe constraints on firms with higher G-index values. We thus expect such firms to be more responsive to the SOX regulations. However, the G-index is known to be a noisy proxy of corporate governance. To mitigate the potential effects of measurement error, we sort firms into terciles on the basis of their G-Index values in each year, and then drop the middle third. We estimate the model as in Column 2 of Table 3 for the top and bottom terciles.

Columns 1 and 2 of Table 5 present the results. In both cases, J-tests do not reject the overidentifying restrictions. The estimated coefficient on $D S O X$, however, differs markedly for the two groups. The estimate is significantly negative for the well-governed firms, but significantly positive for the poorly governed firms. The well-governed firms have become more cautious in making investment in the post-SOX period, and the poorly governed firms appear to have become more aggressive. Therefore, the effects documented by our previous analysis are more significant among well-governed firms.

To check the robustness of this finding, we use Bebchuk, Cohen, and Ferrell's (2009) entrenchment index as another proxy for corporate governance (the E-index). Bebchuk, Cohen, and Ferrell (2009) argue that the E-index better characterizes the corporate governance of U.S. firms than the G-index. As before, we estimate the Euler equation as in Column 2 of Table 3 for firms in the top and the bottom terciles. Columns 3 and 4 of Table 5 report the results, which are largely similar to those for the G-index. Again, the coefficient estimate on $D S O X$ is significantly 
negative for the well-governed firms, but positive for poorly governed firms.

We also use an indicator for whether a firm has a credit rating as a sorting variable (see, e.g., Whited, 1992). All other factors equal, a firm with a credit rating is subject to more scrutiny from outsiders - rating agencies in particular — and is thus expected to be better governed and more transparent than a firm without a credit rating. Also, firms without a credit rating are more financially constrained, and may not have enough resources to comply with SOX. Therefore, we split our U.S. sample into two subsamples according to whether the firm had an S\&P credit rating in the previous year. We then estimate the model in Column 2 of Table 3 for each subsample. Columns 5 and 6 of Table 5 present the results. It is interesting that the estimated coefficient on $D S O X$ is significantly negative for the rated firms and significantly positive for the unrated firms. To the extent that rated firms are likely to be better governed than unrated firms, this suggests that better-governed firms have become more cautious about investment than less well-governed firms in the post-SOX period.

Our analysis so far identifies robust evidence that SOX has profoundly affected the investment decisions of U.S. firms. We expect that these effects should be mitigated for firms that are less subject to the SOX regulations. Firms that are "less subject" to these regulations include firms with a public float of below $\$ 75$ million. Such firms have been permitted by the Securities and Exchange Commission to postpone their compliance with Section 404. To test whether this is the case, we divide the sample into two subsamples according to market value of equity. Firms with market capitalization of less than $\$ 75$ million at the end of the relevant year are classified as non-accelerated filers, while firms with market capitalization greater than $\$ 75$ million are classified as accelerated filers. ${ }^{13}$ Estimates of the benchmark model for these two subsamples are reported in the last two columns of Table 5 . Note in the very last column of Table 5 that the inferred discount rates of accelerated filers rose after the passage of SOX; the estimated coefficient on DSOX is significantly negative at -0.145 , with a standard error of 0.044 . SOX has a much less negative effect on non-accelerated filers' investment — the estimated coefficient is only -0.031 and not significant.

All our subsample analyses provide evidence that the SOX regulations have had differential effects on U.S. firms' investment decisions. Firms with good corporate governance or firms that are

\footnotetext{
${ }^{13}$ Note that some of the non-accelerated filers could be misclassified as accelerated filers if their total market value of equity is greater than $\$ 75$ million but they do not satisfy other criteria for accelerated filers. Such misclassification would bias against our expected results.
} 
rated by rating agencies tend to apply higher discount rates and exert greater caution in making investment after the passage of SOX, whereas firms with poorer governance, firms without a credit rating, or firms that are not immediately subject to the SOX regulations (i.e., non-accelerated filers of Section 404) are less affected by SOX. The greater caution of well-governed firms and rated firms in the post-SOX period may reflect these firms' greater concerns about the risk of not following the SOX regulations and potential damage to their reputation. Preoccupation with compliance thus may discourage them from taking up new and risky investment projects. Such a finding casts doubt on the effectiveness of one-size-fits-all SOX regulations. Indeed, the reforms prescribed by SOX may not reflect best practices in corporate governance for every firm. To the extent that some firms modify an optimal governance structure in order to comply with the SOX requirements, this change would unavoidably affect their optimal investment decisions.

\section{Conclusions}

In this paper, we use an investment Euler equation framework to assess the effects of the SarbanesOxley Act of 2002 on firms' corporate investment decisions. We specify our investment Euler equation in such a way that an indicator for the passage of SOX is allowed to affect the rate at which managers discount investment projects. The key insights of our Euler equation framework are that the optimal level of firm investment is reached by trading off the intertemporal costs and benefits of making investment via an appropriate stochastic discount factor, and that the stochastic discount factor is related to a utility-maximizing manager's preference for risk taking. We apply GMM to estimate parameters of our investment Euler equation and infer the managers' implied discount rates from these estimated parameters.

We find robust evidence that the discount rates managers of U.S. firms apply rise significantly after SOX; the discount rates for U.K. firms, by comparison, remain virtually unchanged over the sample period. This evidence thus lends some support to the conjecture that SOX has had negative effects on corporate investment in the U.S., at least in its initial implementation. We also find evidence that the effects of SOX are not uniform across firms in the U.S. sample. Smaller firms, riskier firms, firms with better corporate governance, firms with a credit rating, and firms classified as accelerated filers of Section 404 all have become more cautious about their capital 
spending after the passage of SOX. Our work represents one of the first structural assessments of how SOX affects real activities. We provide evidence that the SOX regulations may have had some un-intended effects on U.S. firms' investment decisions. The net effect of SOX on the real economy deserves more research. 


\section{References}

[1] Abel, Andrew B., and Janice C. Eberly, 1994, A unified model of investment under uncertainty. American Economic Review, 84(5), 1369-1384.

[2] Ang, Andrew, Robert J. Hodrick, Yuhang Xing, and Xiaoyan Zhang, 2006. The cross-section of volatility and expected returns. Journal of Finance, 61, 259-299.

[3] Ang, Andrew, Robert J. Hodrick, Yuhang Xing, and Xiaoyan Zhang, 2009. High idiosyncratic volatility and low returns: International and further U.S. evidence. Journal of Financial Economics, 91, 1-23.

[4] Bargeron, Leonce, Kenneth Lehn, and Chad Zutter, 2009. Sarbanes-Oxley and corporate risktaking. Journal of Accounting and Economics, forthcoming.

[5] Bebchuk, Lucian A., Alma Cohen, and Allen Ferrell, 2009. What Matters in corporate governance? Review of Financial Studies, 22, 783-827.

[6] Berk, Jonathan B., Richard C. Green, and Vasant Naik, 1999. Optimal investment, growth options, and security returns. Journal of Finance, 54, 1153-1607.

[7] Chhaochharia, Vidhi, Yaniv Grinstein, 2007. Corporate governance and firm value: The impact of the 2002 governance rules. Journal of Fiance, 62, 1789-1825.

[8] Chirinko, R.S., and H. Schaller, 2004. A revealed preference approach to understanding corporate governance problems: Evidence from Canada. Journal of Financial Economics, 74, 181-206.

[9] Cochrane, John H., 1991. Production-based asset pricing and the link between stock returns and economic fluctuations. Journal of Finance, 46, 209-237.

[10] Cochrane, John H., 2001. Asset Pricing. Princeton University Press. Princeton, New Jersey.

[11] Cohen, Daniel A., Aiyesha Dey, and Thomas Z. Lys, 2006. Trends in earnings management and informativeness of earnings annoucements in the pre and post-Sarbanes-Oxley periods. Working paper, New York University and Northwestern University.

[12] DeFond, Mark, Mingyi Hung, Emre Karaoglu, and Jieying Zhang, 2007. Was the SarbanesOxley Act good news for corporate bondholders? Working paper, University of Southern California.

[13] Engel, Ellen, Rachel Hayes, and Xue Wang, 2007. The Sarbanes-Oxley Act and firms' goingprivate decisions. Journal of Accounting Economics, 44, 116-145.

[14] Fama, Eugene F., and Kenneth R. French, 1992, The cross-section of expected stock returns. Journal of Finance, 47, 427-465.

[15] Gao, Feng, Joanna Shuang Wu, and Jerold L. Zimmerman, 2009. Unintened consequences of scaling securities regulation: Evidence form the Sarbanes-Oxley Act. Journal of Accounting Research, 47(2), 459-506.

[16] Gompers, Paul A., Joy L. Ishii, and Andrew Metrick, 2003. Corporate finance and equity prices. Quarterly Journal of Economics, 118 (1), 107-155. 
[17] Heron, Randall A., and Erik Lie, 2006. Does backdaing explain the stock price pattern around executive stock option grants? Journal of Financial Economics, 83, 271-295.

[18] Jegadeesh, Narasimhan, and Sheridan Titman, 1993, Returns to buying winners and selling losers: Implications for stock market efficiency, Journal of Finance 48, 65-91.

[19] Leuz, C., A. J. Triantis, and T. Y. Wang, 2008. Why do firms go dark? Causes and economic consequences of voluntary SEC deregistrations. Journal of Accounting and Economics, 45, 181-208.

[20] Li, H., M. P.K. Pincus, and S. Rego, 2008. Market reaction to events surrounding the SarbanesOxley Act of 2002 and earnings management. Journal of Law and Economics, 51, 111-134.

[21] Li, Xi, 2006. The Sarbanes-Oxley Act and cross-listed foregin private issuers. Working paper, University of Miami.

[22] Linck, J.S., J. M. Netter, and T. Yang, 2008, The effects and unintended conswquences of the Sarbanes-Oxley Act, and its era, on the supply and demand for directors. Review of Financial Studies, forthcoming.

[23] Liu, Laura X., Toni M. Whited, and Lu Zhang, 2007. Investment-based expected stock returns. NBER working paper No. 13024.

[24] Litvak, Kate, 2007. The effect of the Sarbanes-Oxley act on non-US companies cross-listed in the US. Journal of Corporate Finance, 13, 195-228.

[25] Love, Inessa, 2003. Financial development and financing constraints: International evidence from the structural investment model. Review of Financial Studies, 16, 765-791.

[26] Narayanan, M. P. and H. Nejat Seyhun, 2008. The dating game: Do managers designate grant dates to increase their compensation? Review of Financial Studies 21, 1907-1945.

[27] Piotroski, J. D., S. Srinivasan, 2008. Regulation and bonding: The Sarbanes-Oxley Act and the flow of international listings. Journal of Accounting Research, 46, 383-425.

[28] Skaife, A. H., D. W. Collins, W. R. Kinney, and R. LaFond, 2009, The effect of SOX internal control deficiencies on firm risk and cost of equity. Journal of Accounting Research, 47, 1-43.

[29] Whited, Toni M., 1992. Debt, liquidity constraints, and coporate investment: Evidence from panel data. Journal of Finance, 47, 1425-1460.

[30] Whited, Toni M., 1998. Why do investment Euler equations fail? Journal of Business and Economic Statistics, 16, 469-478.

[31] Whited, Toni M., 2006. External finance constraints and the intertemporal pattern of intermittent investment. Journal of Financial Economics, 81, 467-502.

[32] Whited, Toni M., and Guojun Wu, 2006. Financing constraints risk. Review of Financial Studies, 19, 531-559.

[33] Zhang, Ivy, 2007. Economic consequences of the Sarbanes-Oxley Act of 2002. Journal of Accounting and Economics, 44, 74-115.

[34] Zhang, Lu, 2005. The value premium. Journal of Finance, 60, 67-103. 
Table 1 Means of Variables for U.S. and U.K. Firms

This table presents the means of the variables used in the empirical analysis on an annual basis over 1998 - 2005. The U.S. sample is constructed from the Compustat and CRSP databases. The U.K. sample is constructed from the Compustat Global database. In both samples, we exclude financial services firms and firms in regulated industries. We also delete firms with extreme values (i.e., with values outside the $1^{\text {st }}$ percentile and the $99^{\text {th }}$ percentile of the relevant variables) Further, we only include firms with at least three consecutive years of complete data. These screens leave us with an unbalanced panel between 2,479 and 3,048 firms per year for U.S., and between 387 and 707 firms per year for U.K. Investment, $I$, is defined as the capital expenditure (item 30 for U.S. firms and item 193 for U.K. firms) minus the sale of properties, plants, and equipment (item 107 for U.S. firms and item 181 for U.K. firms). The alternative investment definition, $I R$, is computed as the sum of $I$ and R\&D (item 46 for U.S. firms and item 52 for U.K. firms); R\&D is set to zero if the data is missing. $K$ is the total assets at the beginning of the year (item 6 for U.S. firms and item 89 for U.K. firms). $V C$ is the total variable costs incurred in a given year, including cost of goods sold (item 41 for U.S. and item 4 for U.K.) and selling, general, and administrative costs (item 189 for U.S. firms and item 5 for U.K. firms). Sale is total sales (item 12 for U.S. firms and item 1 for U.K. firms). $\beta$ is a firm's beta computed from fitting a CAPM on a rolling basis with monthly returns over the previous five years. For U.S. firms, we measure the market return and the risk-free rate $\left(r_{f}\right)$ by the CRSP value-weighted market index return and the one-month Treasury-Bill rate, respectively; for U.K. firms, we measure the market return and the risk-free rate by the MSCI U.K. index return and the 91-day Government Treasury bill yield, respectively. size is defined as the logarithm of a firm's market capitalization which is the product of the number of shares outstanding at year-end and the stock price at year-end. btm is the ratio of book equity (item 60 plus item 70 for U.S. firms and item 146 for U.K. firms) to market equity. annvol is the annualized standard deviation in monthly stock returns over the previous five years. annret is defined as the past 12-month cumulative stock return. leverage is the ratio of book value of debt (the sum of items 9, 34, and 84 for U.S. firms and item 106 for U.K. firms) to the total assets. All monetary variables are quoted in 1998 dollars. The numbers in brackets under each year indicate the number of firms included in the sample for that year. 
Panel A: U.S. Firms (number of firms listed under each year)

\begin{tabular}{lrrrrrrrr}
\hline \hline & 1998 & 1999 & 2000 & 2001 & 2002 & 2003 & 2004 & 2005 \\
& $(2,634)$ & $(2,866)$ & $(3,048)$ & $(3,030)$ & $(3,003)$ & $(2,934)$ & $(2,740)$ & $(2,479)$ \\
\hline Investment/asset $(I / K)$ & 0.081 & 0.070 & 0.070 & 0.057 & 0.049 & 0.049 & 0.054 & 0.055 \\
Investment/asset $(I R / K)$ & 0.124 & 0.112 & 0.115 & 0.102 & 0.093 & 0.094 & 0.098 & 0.095 \\
R\&D/Asset $(R \& D / K)$ & 0.043 & 0.042 & 0.045 & 0.046 & 0.044 & 0.045 & 0.044 & 0.040 \\
Cost/asset $(V C / K)$ & 1.313 & 1.263 & 1.244 & 1.093 & 1.069 & 1.094 & 1.136 & 1.112 \\
Sale/asset $(Y / K)$ & 1.451 & 1.385 & 1.350 & 1.175 & 1.158 & 1.194 & 1.252 & 1.233 \\
Market Beta $(\beta)$ & 1.215 & 1.284 & 1.223 & 1.294 & 1.357 & 1.383 & 1.404 & 1.439 \\
Risk Free Rate $\left(r_{f}\right)$ & 0.049 & 0.047 & 0.059 & 0.039 & 0.016 & 0.010 & 0.012 & 0.030 \\
Log Market Cap $($ size $)$ & 5.356 & 5.387 & 5.261 & 5.491 & 5.446 & 6.010 & 6.266 & 6.439 \\
book-to-market $($ btm) & 0.676 & 0.724 & 0.907 & 0.745 & 0.854 & 0.569 & 0.515 & 0.511 \\
Annualized stock volatility (annvol) & 0.503 & 0.554 & 0.616 & 0.662 & 0.656 & 0.623 & 0.575 & 0.508 \\
Annualized return $($ annret) & -0.171 & 0.010 & -0.133 & 0.043 & -0.148 & 0.288 & 0.131 & 0.073 \\
Debt/Asset (leverage) & 0.242 & 0.251 & 0.249 & 0.232 & 0.219 & 0.206 & 0.196 & 0.190 \\
\hline
\end{tabular}

Panel B: U.K. Firms (number of firms listed under each year)

\begin{tabular}{lcccccccc}
\hline \hline & $\begin{array}{c}1998 \\
(387)\end{array}$ & $\begin{array}{c}1999 \\
(452)\end{array}$ & $\begin{array}{c}2000 \\
(500)\end{array}$ & $\begin{array}{c}2001 \\
(560)\end{array}$ & $\begin{array}{c}2002 \\
(648)\end{array}$ & $\begin{array}{c}2003 \\
(707)\end{array}$ & $\begin{array}{c}2004 \\
(695)\end{array}$ & $\begin{array}{c}2005 \\
(670)\end{array}$ \\
\hline Investment/asset $(I / K)$ & 0.089 & 0.078 & 0.078 & 0.066 & 0.062 & 0.055 & 0.060 & 0.065 \\
Investment/asset $(I R / K)$ & 0.107 & 0.097 & 0.100 & 0.090 & 0.087 & 0.083 & 0.087 & 0.082 \\
R\&D/Asset $(R \& D / K)$ & 0.019 & 0.019 & 0.022 & 0.024 & 0.025 & 0.028 & 0.027 & 0.017 \\
Cost/asset $(V C / K)$ & 1.157 & 1.133 & 1.127 & 1.026 & 0.995 & 1.022 & 1.080 & 1.127 \\
Sale/asset $(Y / K)$ & 1.476 & 1.402 & 1.376 & 1.235 & 1.163 & 1.186 & 1.254 & 1.252 \\
Market Beta $(\beta)$ & 0.694 & 0.690 & 0.628 & 0.728 & 0.830 & 0.897 & 0.917 & 1.004 \\
Risk Free Rate $\left(r_{f}\right)$ & 0.055 & 0.055 & 0.056 & 0.037 & 0.036 & 0.037 & 0.043 & 0.042 \\
Log Market Cap $($ size $)$ & 4.693 & 4.820 & 4.691 & 4.470 & 4.101 & 4.449 & 4.593 & 4.694 \\
book-to-market $($ btm) & 0.758 & 0.709 & 0.813 & 0.827 & 0.925 & 0.620 & 0.580 & 0.563 \\
Annualized stock volatility (annvol) & 0.232 & 0.266 & 0.290 & 0.285 & 0.288 & 0.309 & 0.288 & 0.275 \\
Annualized return $($ annret) & 0.057 & 0.164 & 0.096 & 0.023 & -0.017 & 0.135 & 0.133 & 0.176 \\
Debt/Asset (leverage) & 0.476 & 0.444 & 0.438 & 0.436 & 0.441 & 0.441 & 0.447 & 0.469 \\
\hline
\end{tabular}


Table 2 GMM Estimates of Investment Euler Equation on the Pooled Sample

We estimate our investment Euler equation on the pooled sample consisting of both U.S. firms and U.K. firms for 1998 - 2005. The number of firms varies from year to year (see Table 1 ). $I / K$ is used as the measure of investment. Table 1 defines the variables. $\alpha_{2}$ and $\alpha_{3}$ are adjustment cost parameters, and $\mu$ is mark-up. $D S O X$ is a dummy variable that takes the value of 1 for the postSOX period $\left(2003,2004\right.$, and 2005) and 0 otherwise. $D^{U \mathrm{~S}}$ is a dummy variable that equals 1 for U.S. firms and 0 otherwise. Nonlinear GMM estimation is done on the model in first differences with twice lagged instrumental variables. The estimations hence are based on the observations from 2000 to 2005 . For all estimations, we include 17 instruments: constant; risk-free rate $\left(r_{f}\right)$, $Y / K, V C / K, I / K, \beta$, size, btm, annvol, annret, leverage, each lagged by two periods; $D^{U \mathrm{~S}}$; the interactions of $D^{U \mathrm{~S}}$ with the following five variables: $\beta$, size, btm, annret, each lagged by two periods, and $D S O X$. The $\chi^{2}$ values, degree of freedom, and $\mathrm{p}$-values from the J-test (overidentifying restrictions) and the L-test (variable exclusion restrictions) on model specifications are reported in the bottom section of the table. Standard errors are in parentheses.

\begin{tabular}{|c|c|c|c|c|}
\hline & (1) & (2) & (3) & (4) \\
\hline \multirow[t]{2}{*}{$\alpha_{2}$} & 1.379 & 0.768 & 0.388 & -0.259 \\
\hline & $(0.912)$ & $(0.449)$ & $(0.499)$ & $(0.218)$ \\
\hline \multirow[t]{2}{*}{$\alpha_{3}$} & -1.188 & -0.912 & -0.452 & -0.716 \\
\hline & $(0.672)$ & $(0.647)$ & $(0.288)$ & $(0.396)$ \\
\hline \multirow[t]{2}{*}{$\mu$} & 1.039 & 1.187 & 1.070 & 1.136 \\
\hline & $(0.013)$ & $(0.054)$ & $(0.044)$ & $(0.021)$ \\
\hline \multirow[t]{2}{*}{ DSOX } & 0.017 & 0.018 & 0.022 & -0.077 \\
\hline & $(0.015)$ & $(0.014)$ & $(0.117)$ & $(0.052)$ \\
\hline \multirow[t]{2}{*}{$\mathrm{D}^{\mathrm{US}}$} & -0.815 & -0.810 & -0.983 & \\
\hline & $(0.304)$ & $(0.351)$ & $(0.042)$ & \\
\hline \multirow{2}{*}{$\mathbf{D}^{\mathrm{US}} \times \mathbf{D S O X}$} & -0.066 & -0.069 & -0.064 & \\
\hline & $(0.034)$ & $(0.035)$ & $(0.039)$ & \\
\hline \multirow[t]{2}{*}{ Firm size (size) } & -0.163 & -0.194 & -0.260 & -0.184 \\
\hline & $(0.075)$ & $(0.041)$ & $(0.043)$ & $(0.029)$ \\
\hline \multirow[t]{2}{*}{ Book-to-market equity (btm) } & -0.111 & -0.058 & -0.497 & -0.199 \\
\hline & $(0.078)$ & $(0.039)$ & $(0.128)$ & $(0.072)$ \\
\hline \multirow[t]{2}{*}{ Market beta $(\beta)$} & -0.245 & -0.215 & & -0.123 \\
\hline & $(0.109)$ & $(0.091)$ & & $(0.041)$ \\
\hline \multirow[t]{2}{*}{ Previous-year return (annret) } & 0.426 & & & \\
\hline & $(0.390)$ & & & \\
\hline \multirow[t]{2}{*}{ size $\times D^{\text {US }}$} & 0.059 & 0.154 & 0.256 & \\
\hline & $(0.162)$ & $(0.057)$ & $(0.036)$ & \\
\hline \multirow{2}{*}{$\mathrm{btm} \times \mathrm{D}^{\mathrm{US}}$} & -0.202 & -0.005 & 0.485 & \\
\hline & $(0.401)$ & $(0.067)$ & $(0.138)$ & \\
\hline \multirow{2}{*}{$\beta \times D^{U S}$} & 0.325 & 0.213 & & \\
\hline & $(0.215)$ & $(0.089)$ & & \\
\hline \multirow{2}{*}{ annret $\times \mathrm{D}^{\mathrm{US}}$} & -0.548 & & & \\
\hline & $(0.461)$ & & & \\
\hline \multirow{6}{*}{$\begin{array}{l}\chi^{2} \text { (over-identifying restrictions) } \\
\text { degrees of freedom } \\
p \text { value of J-test } \\
\chi^{2} \text { (exclusion restrictions) } \\
\text { degrees of freedom } \\
p \text { value of L-test }\end{array}$} & 3.879 & 4.367 & 10.011 & 22.101 \\
\hline & 3 & 5 & 7 & 10 \\
\hline & 0.274 & 0.498 & 0.188 & 0.015 \\
\hline & $\mathrm{n} / \mathrm{a}$ & 0.488 & 5.641 & 17.734 \\
\hline & $\mathrm{n} / \mathrm{a}$ & 2 & 2 & 5 \\
\hline & $\mathrm{n} / \mathrm{a}$ & 0.783 & 0.060 & 0.003 \\
\hline
\end{tabular}


Table 3 GMM Estimates of Investment Euler Equation on U.S. Firms and U.K. Firms We estimate investment Euler equations on U.S. and U.K. firms separately. In both samples, $I / K$ is used as the measure of investment. Table 1 defines all the variables. $\alpha_{2}$ and $\alpha_{3}$ are adjustment cost parameters, and $\mu$ is mark-up. $D S O X$ is a dummy variable that takes the value of 1 for the post-SOX period (years 2003, 2004 and 2005) and 0 otherwise. Nonlinear GMM estimation is done on the model in first differences with twice lagged instrumental variables. The estimations hence are based on the observations from 2000 to 2005. For all estimations, we include 11 instruments: constant; risk-free rate $\left(r_{f}\right), Y / K, V C / K, I / K, \beta$, size, btm, annvol, annret, and leverage, each lagged by two periods. The $\chi^{2}$ values, degree of freedom, and $p$-values from the J-test (overidentification restriction test) and the L-test (variable exclusion restriction test) on model specifications are reported in the bottom section of the table. Standard errors are in parentheses.

\begin{tabular}{|c|c|c|c|c|}
\hline & \multicolumn{2}{|c|}{ U.S. firms } & \multicolumn{2}{|c|}{ U.K. firms } \\
\hline & $(1)$ & $(2)$ & (3) & (4) \\
\hline \multirow[t]{2}{*}{$\alpha_{2}$} & 0.697 & 0.872 & 0.401 & 0.381 \\
\hline & $(1.429)$ & $(0.623)$ & $(0.652)$ & $(0.561)$ \\
\hline \multirow[t]{2}{*}{$\alpha_{3}$} & -0.712 & -0.776 & 1.119 & 1.594 \\
\hline & $(0.558)$ & $(0.456)$ & $(2.224)$ & $(1.091)$ \\
\hline \multirow[t]{2}{*}{$\mu$} & 1.065 & 1.148 & 0.966 & 0.968 \\
\hline & $(0.022)$ & $(0.033)$ & $(0.112)$ & $(0.114)$ \\
\hline \multirow[t]{2}{*}{ DSOX } & -0.104 & -0.132 & -0.001 & -0.001 \\
\hline & $(0.064)$ & $(0.069)$ & $(0.072)$ & $(0.074)$ \\
\hline \multirow[t]{2}{*}{ Firm size (Size) } & -0.102 & -0.101 & 0.033 & 0.044 \\
\hline & $(0.069)$ & $(0.063)$ & $(0.087)$ & $(0.055)$ \\
\hline \multirow{2}{*}{ Book-to-market equity (btm) } & -0.056 & -0.412 & -0.071 & -0.083 \\
\hline & $(0.254)$ & $(0.126)$ & $(0.093)$ & $(0.063)$ \\
\hline \multirow[t]{2}{*}{ Market beta $(\beta)$} & -0.122 & -0.155 & -0.763 & -0.789 \\
\hline & $(0.062)$ & $(0.057)$ & $(0.176)$ & $(0.094)$ \\
\hline \multirow[t]{2}{*}{ Previous-year return (annret) } & 0.669 & & 0.062 & \\
\hline & $(0.524)$ & & $(0.341)$ & \\
\hline$\chi^{2}$ (over-identifying restrictions) & 5.587 & 6.017 & 1.128 & 1.571 \\
\hline degrees of freedom & 3 & 4 & 3 & 4 \\
\hline$p$ value of J-test & 0.201 & 0.198 & 0.760 & 0.814 \\
\hline$\chi^{2}$ (exclusion restriction test) & $\mathrm{n} / \mathrm{a}$ & 0.430 & $\mathrm{n} / \mathrm{a}$ & 0.443 \\
\hline degrees of freedom & $\mathrm{n} / \mathrm{a}$ & 1 & $\mathrm{n} / \mathrm{a}$ & 1 \\
\hline$p$ value of L-test & $\mathrm{n} / \mathrm{a}$ & 0.512 & $\mathrm{n} / \mathrm{a}$ & 0.506 \\
\hline
\end{tabular}


Table 4 GMM Estimates of Investment Euler Equations for U.S. Firms with an Extended Stochastic Discount Factor Equation

This U.S. sample consists of between 2479 and 3048 unregulated and nonfinancial U.S. firms for the period from 1998 to $2005 . I / K$ is used as the measure of investment. Table 1 defines all the variables. $\alpha_{2}$ and $\alpha_{3}$ are adjustment cost parameters, and $\mu$ is mark-up. DSOX is a dummy variable that takes the value of 1 for the post-SOX period (years 2003, 2004 and 2005) and 0 otherwise. Nonlinear GMM estimation is done on the model in first differences with twice lagged instrumental variables. The estimations hence are based on the observations from 2000 to 2005 . In the last column, we estimate our investment Euler equation on a balanced panel, which consists of 1,825 unique firms from 1998 to 2005. For all estimations, we include 11 instruments: constant; risk-free rate $\left(r_{f}\right), Y / K, V C / K, I / K, \beta$, size, btm, annvol, annret, and leverage, each lagged by two periods. The $\chi^{2}$ values, degree of freedom, and $p$-values from the J-test (overidentification restriction test) and the L-test (variable exclusion restriction test) on model specifications are reported in the bottom section of the table. Standard errors are in parentheses.

\begin{tabular}{|c|c|c|c|c|}
\hline & (1) & (2) & (3) & (4) \\
\hline \multirow[t]{2}{*}{$\alpha_{2}$} & 0.872 & 0.457 & 0.257 & -0.563 \\
\hline & $(0.623)$ & $(1.664)$ & $(0.119)$ & $(0.141)$ \\
\hline \multirow[t]{2}{*}{$\alpha_{3}$} & -0.776 & -0.987 & -0.768 & 1.232 \\
\hline & $(0.456)$ & $(1.182)$ & $(0.506)$ & $(0.671)$ \\
\hline \multirow[t]{2}{*}{$\mu$} & 1.148 & 1.078 & 0.912 & 0.841 \\
\hline & $(0.033)$ & $(0.034)$ & $(0.050)$ & $(0.097)$ \\
\hline \multirow[t]{2}{*}{ DSOX } & -0.132 & -0.705 & -0.747 & 0.049 \\
\hline & $(0.069)$ & (0.199) & $(0.331)$ & $(0.053)$ \\
\hline \multirow{2}{*}{ Firm size (size) } & -0.101 & -0.210 & -0.028 & -0.061 \\
\hline & $(0.063)$ & $(0.078)$ & $(0.060)$ & $(0.078)$ \\
\hline \multirow[t]{2}{*}{ Book-to-market equity (btm) } & -0.412 & -0.277 & -0.611 & -0.704 \\
\hline & $(0.126)$ & $(0.145)$ & $(0.293)$ & $(0.251)$ \\
\hline \multirow[t]{2}{*}{ Market beta $(\beta)$} & -0.155 & -0.034 & -0.037 & -0.162 \\
\hline & $(0.057)$ & $(0.088)$ & $(0.159)$ & $(0.401)$ \\
\hline Size $\times$ DSOX & & $\begin{array}{c}0.113 \\
(0.042)\end{array}$ & & \\
\hline $\mathrm{btm} \times \mathrm{DSOX}$ & & & $\begin{array}{c}0.447 \\
(0.687)\end{array}$ & \\
\hline$\beta \times \mathrm{DSOX}$ & & & & $\begin{array}{r}-0.440 \\
(0.269)\end{array}$ \\
\hline \multirow{6}{*}{$\begin{array}{l}\chi^{2} \text { (over-identifying restrictions) } \\
\text { degrees of freedom } \\
p \text { value of J-test } \\
\chi^{2} \text { (exclusion restriction test) } \\
\text { degrees of freedom } \\
p \text { value of L-test }\end{array}$} & 6.017 & 5.801 & 5.268 & 5.941 \\
\hline & 4 & 3 & 3 & 3 \\
\hline & 0.198 & 0.122 & 0.153 & 0.115 \\
\hline & $\mathrm{n} / \mathrm{a}$ & 0.216 & 0.749 & 0.076 \\
\hline & $\mathrm{n} / \mathrm{a}$ & 1 & 1 & 1 \\
\hline & $\mathrm{n} / \mathrm{a}$ & 0.671 & 0.387 & 0.783 \\
\hline
\end{tabular}




\section{Table 5 GMM Estimates of Investment Euler Equations for Subsamples of U.S. Firms}

We first merge our full U.S. sample with firms having the G-Index (Gompers, Ishii and Metrick, 2003) and the E-Index (Bebchuk, Cohen and Ferrell, 2008) values available. Because data on the G-index (E-index) are available in alternate years, for each firm we extrapolate for the years with missing Gindex (E-index) values by setting the value to its value in previous year. For each year, we divide the sample into three equal-sized sub-groups based on the G-Index or E-Index values in that year. We estimate investment Euler equation on firms in the bottom and top panels respectively (sorted by the GIndex and E-Index) and report the results in the first four columns. The two sub-groups consist of between 264 and 390 firms per year for $1998-2005$. We then divide the U.S. sample into two sub-samples based on whether or not these firms have S\&P credit ratings in the previous year. The first subgroup consists of between 730 and 830 firms per year for the period from 1998 to 2005 . The second sub-panel consists of between 2100 and 2620 firms per year for 1998 - 2005. We estimate investment Euler equation on firms in each of the two sub-groups and report results in the next two columns. We then divide the U.S. sample into two sub-groups by the market value of equity. Firms with market capitalizations less than $\$ 75$ million at the end of the relevant year are classified as non-accelerated filers (these firms can postpone their compliance with Section 404 of SOX). Firms with market capitalizations greater than $\$ 75$ million are classified as accelerated filers. We estimate investment Euler equation on firms in each sub-group and report results in the last two columns. In the table, $I / K$ is used as the measure of investment. Table 1 defines all the variables. $\alpha_{2}$ and $\alpha_{3}$ are adjustment cost parameters, and $\mu$ is mark-up. DSOX is a dummy variable that takes the value of 1 for the post-SOX period (years 2003, 2004 and 2005) and 0 otherwise. We apply GMM to estimate investment Euler equation in first-order differences, which calls for using two-period-lagged investment Euler equation variables as instruments. Consequently, the estimations are based on the observations from 2000 to 2005. For all estimations, we include 11 instruments: constant; risk-free rate $\left(r_{f}\right), Y / K, V C / K, I / K, \beta$, size, btm, annvol, annret, and leverage, each lagged by two periods. The $\chi^{2}$ values, degree of freedom, and p-values from the J-test (over-identification restriction test) are reported in the bottom section of the table. Standard errors are in parentheses. 


\begin{tabular}{|c|c|c|c|c|c|c|c|c|}
\hline & \multicolumn{2}{|c|}{ By G-Index } & \multicolumn{2}{|c|}{ By E-Index } & \multicolumn{2}{|c|}{ By S\&P Credit Ratings } & \multicolumn{2}{|c|}{ By Market Value of Equity } \\
\hline & $\begin{array}{c}\text { top one- } \\
\text { third } \\
{[265-390]} \\
(1)\end{array}$ & $\begin{array}{c}\text { bottom } \\
\text { one-third } \\
{[264-390]} \\
(2)\end{array}$ & $\begin{array}{c}\text { top one- } \\
\text { third } \\
{[265-390]} \\
(3)\end{array}$ & $\begin{array}{l}\text { bottom one- } \\
\text { third } \\
{[264-390]} \\
(4)\end{array}$ & $\begin{array}{c}\text { w. rating } \\
{[730-} \\
870] \\
(5)\end{array}$ & $\begin{array}{c}\text { w/out rating } \\
{[2100-} \\
2620] \\
(6)\end{array}$ & $\begin{array}{l}\text { smaller } \\
\text { than } \$ 75 \mathrm{M} \\
{[601-711]} \\
(7)\end{array}$ & $\begin{array}{c}\text { larger than } \\
\$ 75 \mathrm{M} \\
{[2512-2600]} \\
(8)\end{array}$ \\
\hline$\alpha_{2}$ & $\begin{array}{c}-0.824 \\
(0.532)\end{array}$ & $\begin{array}{c}0.535 \\
(0.219)\end{array}$ & $\begin{array}{l}-0.946 \\
(0.472)\end{array}$ & $\begin{array}{c}0.777 \\
(0.796)\end{array}$ & $\begin{array}{c}0.686 \\
(0.866)\end{array}$ & $\begin{array}{l}-0.218 \\
(0.556)\end{array}$ & $\begin{array}{l}-0.752 \\
(1.334)\end{array}$ & $\begin{array}{c}0.499 \\
(0.439)\end{array}$ \\
\hline$\alpha_{3}$ & $\begin{array}{c}1.118 \\
(0.924)\end{array}$ & $\begin{array}{l}-0.138 \\
(0.602)\end{array}$ & $\begin{array}{c}1.208 \\
(1.118)\end{array}$ & $\begin{array}{l}-0.232 \\
(0.201)\end{array}$ & $\begin{array}{l}-0.175 \\
(0.117)\end{array}$ & $\begin{array}{c}0.492 \\
(0.134)\end{array}$ & $\begin{array}{c}0.478 \\
(1.036)\end{array}$ & $\begin{array}{l}-0.397 \\
(0.368)\end{array}$ \\
\hline$\mu$ & $\begin{array}{c}0.986 \\
(0.057)\end{array}$ & $\begin{array}{c}1.037 \\
(0.014)\end{array}$ & $\begin{array}{c}0.942 \\
(0.076)\end{array}$ & $\begin{array}{c}1.114 \\
(0.065)\end{array}$ & $\begin{array}{c}1.130 \\
(0.024)\end{array}$ & $\begin{array}{c}1.005 \\
(0.028)\end{array}$ & $\begin{array}{c}0.940 \\
(0.141)\end{array}$ & $\begin{array}{c}0.997 \\
(0.045)\end{array}$ \\
\hline DSOX & $\begin{array}{c}0.078 \\
(0.025)\end{array}$ & $\begin{array}{c}-0.068 \\
(0.039)\end{array}$ & $\begin{array}{c}0.091 \\
(0.052)\end{array}$ & $\begin{array}{c}-0.117 \\
(0.063)\end{array}$ & $\begin{array}{c}-0.171 \\
(0.031)\end{array}$ & $\begin{array}{c}0.029 \\
(0.010)\end{array}$ & $\begin{array}{c}-0.031 \\
(0.025)\end{array}$ & $\begin{array}{c}-0.145 \\
(0.044)\end{array}$ \\
\hline Firm size (size) & $\begin{array}{c}-0.103 \\
(0.017)\end{array}$ & $\begin{array}{c}0.033 \\
(0.103)\end{array}$ & $\begin{array}{l}-0.099 \\
(0.021)\end{array}$ & $\begin{array}{l}-0.103 \\
(0.052)\end{array}$ & $\begin{array}{c}-0.206 \\
(0.039)\end{array}$ & $\begin{array}{l}-0.084 \\
(0.009)\end{array}$ & $\begin{array}{l}-0.240 \\
(0.032)\end{array}$ & $\begin{array}{l}-0.004 \\
(0.027)\end{array}$ \\
\hline Book-to-market equity (btm) & $\begin{array}{c}-0.056 \\
(0.090)\end{array}$ & $\begin{array}{l}-0.133 \\
(0.206)\end{array}$ & $\begin{array}{l}-0.032 \\
(0.076)\end{array}$ & $\begin{array}{l}-0.288 \\
(0.168)\end{array}$ & $\begin{array}{c}-0.386 \\
(0.090)\end{array}$ & $\begin{array}{l}-0.042 \\
(0.014)\end{array}$ & $\begin{array}{c}-0.284 \\
(0.054)\end{array}$ & $\begin{array}{l}-0.052 \\
(0.126)\end{array}$ \\
\hline Market beta $(\beta)$ & $\begin{array}{l}-0.113 \\
(0.036)\end{array}$ & $\begin{array}{l}-0.294 \\
(0.097)\end{array}$ & $\begin{array}{l}-0.103 \\
(0.051)\end{array}$ & $\begin{array}{l}-0.352 \\
(0.081)\end{array}$ & $\begin{array}{l}-0.029 \\
(0.031)\end{array}$ & $\begin{array}{l}-0.018 \\
(0.027)\end{array}$ & $\begin{array}{l}-0.040 \\
(0.046)\end{array}$ & $\begin{array}{l}-0.327 \\
(0.058)\end{array}$ \\
\hline $\begin{array}{l}\chi^{2} \text { (over-identifying restrictions) } \\
\text { degree of freedom }\end{array}$ & $\begin{array}{l}4.750 \\
4\end{array}$ & $\begin{array}{c}4.265 \\
4\end{array}$ & $\begin{array}{c}0.734 \\
4\end{array}$ & $\begin{array}{c}1.029 \\
4\end{array}$ & $\begin{array}{c}1.172 \\
4\end{array}$ & $\begin{array}{c}9.138 \\
4\end{array}$ & $\begin{array}{c}8.237 \\
4\end{array}$ & $\begin{array}{c}4.994 \\
4\end{array}$ \\
\hline$p$ value of J-test & 0.314 & 0.371 & 0.947 & 0.905 & 0.883 & 0.058 & 0.083 & 0.288 \\
\hline
\end{tabular}


Figure 1 The Investment Implied Discount Rate from 1998 to 2005: U.S. vs. U.K.

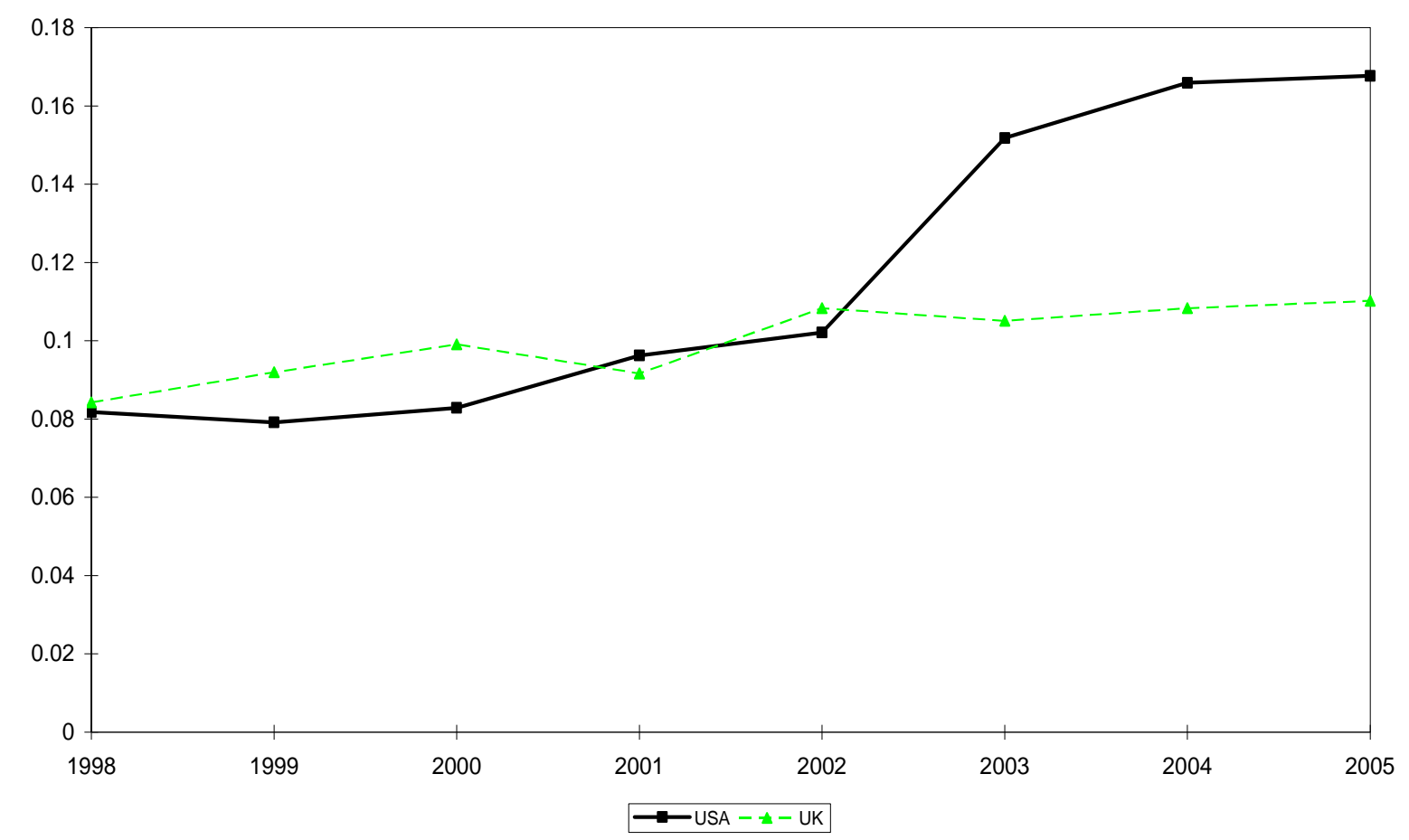

Note: We assume that the average discount rates for both U.S. and U.K. firms are $10 \%$ over 1998-2005. This assumption allows us to estimate the value of the constant term $1_{0}$ for both U.S. and U.K. firms, which is 1.917 for U.S and 1.677 for U.K. Based on the estimated coefficients, we compute the investment-based discount rate for each firm-year observation. We eliminate observations with extreme discount rate values in our analysis. Specifically, in each year, we delete separately U.S. and U.K. firms with their discount rates smaller than the 5th percentile or larger than 95th percentiles. For the remaining firms, we then calculate separately yearly averages for U.S. firms and U.K. firms. The figure plots these yearly averages for U.S. and U.K respectively. 